\title{
PENINGKATAN KETERAMPILAN GURU SD DABIN III UPTD DIKDAS DAN LS WONOSEGORO - BOYOLALI DALAM MENGELOLA KELAS MELALUI TEKNIK SUPERVISI INDIVIDUAL
}

\author{
Beni Supadmono \\ benisupadmono1959@gmail.com \\ UPTD Dikdas dan LS Kecamatan Wonosegoro - Boyolali
}

\begin{abstract}
ABSTRAK
Penelitian ini bertujuan untuk mengetahui: 1) pelaksanaan supervisi individual dalam rangka meningkatkan keterampilan guru mengelola kelas dalam mengajar di Wilayah Daerah Binaan (Dabin) III Unit Pelaksana Teknis Daerah (UPTD) Pendidikan Dasar (Dikdas) dan Luar Sekolah (LS) Kecamatan Wonosegoro Kabupaten Boyolali; 2) Efektivitas penerapan supervisi individual dalam rangka meningkatkan keterampilan guru mengelola kelas dalam mengajar di Wilayah Dabin III UPTD Dikdas dan LS Kecamatan Wonosegoro Kabupaten Boyolali. Jenis penelitian adalah Penelitian Tindakan Sekolah (PTS), dengan prosedur penelitian meliputi persiapan, pelaksanaan, evaluasi, dan refleksi. Teknik pengumpulan data menggunakan: observasi, wawancara, dan dokumentasi. Penelitian ini dilakukan pada guru SD kelas 5 di wilayah Dabin III UPTD Dikdas dan LS Wonosegoro Boyolali yang berjumlah 6 orang. Analisis data dilakukan dengan menggunakan analisis deskriptif komparatif yaitu membandingkan kondisi awal sebelum dilakukan tindakan, hasil siklus 1, dan siklus 2. Hasil penelitian menunjukkan temuan bahwa supervisi individu dapat meningkakan keterampilan guru dalam mengelola kelas di wilayah Dabin III UPTD Dikdas dan LS Kecamatan Wonosegoro-Boyolali. Persentase kenaikan keterampilan guru dalam mengelola kelas sebesar $10 \%$ untuk siklus 1 dan $10,5 \%$ untuk siklus 2 .
\end{abstract}

Kata kunci: Supervisi Individuial, Keterampilan Guru dalam Mengelola Kelas.

\section{PENDAHULUAN}

Guru merupakan tenaga professional yang mempunyai peranan penting dalam proses pembelajaran. Adam dan Decey seperti dikutip oleh Usman (2005: 9) mengemukakan bahwa guru sebagai pengajar, pemimpin kelas, pembimbing, pengatur lingkungan, partisipan, ekspeditor, perencana, supervisor, motivator, dan konselor. Dengan demikian guru mempunyai peranan yang sangat strategis dalam menetukan kualitas pendidikan dan prestasi peserta didik. Menurut Lawrence Stenhouse (dalam Syamsuddin dan Damaianti, 2007: 226) menjelaskan bahwa guru yang profesional adalah guru yang memiliki kemandirian dalam melaksanakan tugas profesinya. 
Salah satu usaha untuk meningkatkan kualitas sumber daya manusia ialah melalui proses pembelajaran di sekolah. Dalam usaha meningkatkan kualitas sumber daya pendidikan, guru merupakan komponen sumber daya manusia yang harus dibina dan dikembangkan terus menerus. Untuk itu, agar para guru mampu melaksanakan tugas-tugas yang menjadi tanggung jawabnya di sekolah perlu senantiasa mendapat penyegaran dalam bentuk bantuan teknis. Bantuan teknis ini diberikan kepada guru sebagai upaya peningkatan kapasitas secara terus menerus. Bantuan tersebut dalam bentuk supervisi akademik yang dilakukan oleh pengawas sekolah. Maksudnya, pengawas sekolah melaksanakan supervisi akademik untuk memberikan bantuan pembinaan dan perbaikan kinerja guru agar dapat mencapai tujuan pendidikan nasional. Supervisi atau pembinaan guru tersebut lebih menekankan pada pembinaan profesional guru yakni pembinaan yang lebih diarahkan pada upaya memperbaiki dan meningkatkan kemampuan profesional guru. Guru yang profesional sangat penting bagi pembentukan sekolah unggulan. Guru profesional mampu mengelola kelas dengan baik.

Pengelolaan kelas merupakan tantangan penting yang dihadapi guru. Seorang guru akan dikenal baik oleh siswa, guru lain, sekolah, dan orang tua siswa bila kemampuan mengelola kelasnya juga baik, yaitu: dapat menangani pembelajaran, menciptakan lingkungan belajar yang tertib, dan menangani berbagai permasalahan dan perilaku siswa. Dengan pengelolaan kelas yang baik dalam pembelajaraan maka proses pembelajaran akan berlangsung secara efektif dan efesien sehingga hasil belajar yang akan diinginkan akan tercapai. Menurut Syaiful Bahri Djamarah dan Aswan Zain (2010: 174) bahwa, Setiap guru masuk kedalam kelas, maka saat itu pula ia memiliki dua masalah pokok, yaitu masalah pengajaran dan masalah manajemen. Masalah pengajaran adalah usaha membantu anak didik dalam mencapai tujuan khusus pengajaran secara langsung, sedangkan masalah manajemen adalah usaha untuk menciptakan dan mempertahankan kondisi sedemikian rupa sehingga proses belajar belajar mengajar dapat berlangsung secara efektif dan efesien.

Namun pada kenyataannya masih jauh dari harapan. Hasil pengamatan dari peneliti di wilayah Dabin III UPTD Dikdas dan LS Kecamatan WonosegoroBoyolali menunjukkan bahwa kemampuan guru dalam pengelolaan kelas masih perlu ditingkatkan, karena guru cenderung monoton dalam mengajar dan kurang mengembangkan metode atau media pembelajaran yang mampu mendorong siswa untuk dapat terlibat aktif dalam proses pembelajaran. Suasana pembelajaran yang cenderung monoton, mengakibatkan anak didik mengikuti proses belajar mengajar kurang bersemangat, karena dianggap kegiatan rutinitas

Hasil wawancara dengan guru kelas 5 di Wilayah Dabin III UPTD Dikdas dan LS Kecamatan Wonosegoro-Boyolali, menunjukkan tingkat keterampilan mengelola kelas dalam mengajar: 1) hanya 2 guru (33\%) tingkat keterampilan 
mengelola kelas dalam mengajar yang tinggi. 2) hanya 1 guru (17\%) tingkat keterampilan mengelola kelas dalam mengajar yang sedang. 3) hanya 3 guru (50\%) tingkat keterampilan mengelola kelas dalam mengajar yang rendah.

Berdasarkan fenomena diatas peneliti berupaya melakukan perbaikan dalam rangka peningkatan mutu pendidikan di sekolah. menggunakan supervisi individual. Kajian pustaka yang dilakukan peneliti menemukan informasi mengenai kegiatan supervisi yang sangat potensial untuk meningkatkan keterampilan guru dalam mengelola kelas.

Ditjen PMPTK (2008: 8) menyebutkan bahwa ada dua teknik dalam supervisi yaitu teknik individual dan teknik kelompok. Dari dua teknik supervisi yang ada, teknik supervisi individual merupakan kegiatan yang sangat potensial untuk meningkatkan kompetensi keterampilan guru dalam mengelola kelas. Potensi teknik supervisi individual tersebut oleh karena lingkupnya langsung pada kegiatannya pembelajaran.

Berdasarkan latar belakang seperti tersebut di atas, permasalahan penelitian yang akan dipecahkan adalah Apakah melalui supervisi individual mampu meningkatkan keterampilan guru mengelola kelas dalam mengajar di Wilayah Dabin III UPTD Dikdas dan LS Kecamatan Wonosegoro Kabupaten Boyolali dan Bagaimana pelaksanaan supervisi individual dalam meningkatkan keterampilan guru mengelola kelas dalam mengajar di wilayah Dabin III UPTD Dikdas dan LS Kecamatan Wonosegoro Kabupaten Boyolali.

\section{KAJIAN PUSTAKA}

\section{Keterampilan Mengelola Kelas}

Menurut Iskandar (2009: 210-211) pengelolaan kelas merupakan kegiatan yang terencana dan sengaja dilakukan oleh guru dengan tujuan menciptakan dan mempertahankan kondisi yang optimal, sehingga proses pembelajaran dapat berjalan secara efektif dan efisien". Sedangkan Ade Rukmana \& Asep Suryana, (2006: 29) menjelaskan bahwa pengelolaan kelas adalah segala usaha yang diarahkan untuk mewujudkan suasana pembelajaran yang efektif dan menyenangkan serta dapat memotivasi siswa untuk belajar dengan baik sesuai dengan kemampuan.

Definisi pengelolaan kelas yang dipaparkan di atas, dapat disimpulkan bahwa pengelolaan kelas lebih menitik beratkan kepada penciptaan suasana belajar yang efektif. Hal ini dikarenakan belajar tanpa suasana yang efektif dan mendorong siswa untuk belajar, akan menjadikan siswa merasa terpaksa untuk belajar di dalam kelas.

Berbeda dengan Iskandar (2009: 210), Ade Rukmana \& Asep Suryana, (2006: 29), Djamarah (2000: 144) menjelaskan bahwa pengelolaan kelas merupakan keterampilan guru untuk menciptakan dan memelihara kondisi belajar yang optimal 
dan mengembalikannya bila terjadi gangguan dalam proses interksi edukatif. Dengan kata lain, kegiatan-kegiatan untuk menciptakan dan mempertahankan kondisi yang optimal bagi terjadinya proses interaksi edukatif.

Wardani (2005: 34) menjelaskan bahwa keterampilan mengelola kelas merupakan keterampilan dalam menciptakan dan mempertahankan kondisi kelas yang optimal guna terjadinya proses belajar-mengajar yang serasi dan efektif.

Menurut Usman (2005: 10) pengelolaan kelas mempunyai tujuan yaitu untuk 1) menyediakan dan menggunakan fasilitas belajar untuk bermacam-macam kegiatan pembelajaran agar mencapai hasil yang baik. 2) mengembangkan kemampuan siswa dengan menggunakan alat-alat belajar, 3) menyediakan kondisikondisi yang memungkinkan siswa belajar. 4) membantu siswa untuk memperoleh hasil yang diharapkan.

Dalam rangka mendukung terjadinya proses pembelajaran, Wardani (2005:35) menyebutkan unsur-unsur dalam mengelola kelas yaitu: 1) keterampilan yang berhubungan dengan penciptaan dan pemeliharaan kondisi belajar yang optimal yaitu (a) menunjukkan sikap tanggap dengan cara: memandang secara seksama, mendekati, memberikan pernyataan atau memberi reaksi terhadap gangguan dalam kelas. (b) membagi perhatian secara visual dan verbal. (c) memusatkan perhatian kelompok dengan cara menyiapkan siswa dan menuntut tanggung jawab siswa. (d) memberi petunjuk-petunjuk yang jelas. (e) menegur secara bijaksana, yaitu secara jelas dan tegas, bujukan berupa peringatan atau ocehan, serta membuat aturan. (f) memberi penguatan bila perlu. 2) keterampilan yang berhubungan dengan pengendalian kondisi belajar yang optimal. Keterampilan ini berkaitan dengan respon guru terhadap respon negatif siswa yang berkelanjutan, keterampilan ini meliputi: a) modifikasi tingkah laku b) pengelolaan (proses) kelompok, c) menemukan dan mengatasi perilaku yang menimbulkan masalah.

Guna memperkecil masalah gangguan dalam kelas, prinsip-prinsip pengelolaan kelas dapat dipergunakan. Maka sangat penting bagi guru untuk mengetahui dan menguasai prinsip-prinsip pengeloalan kelas. Wardani (2005:38), menyebutkan prinsip-prinsip keterampilan mengelola kelas yaitu: 1) kehangatan dan keantusiasan dalam mengajar, yang dapat menciptakan iklim kelas yang menyenangkan. 2) menggunakan kata-kata atau tindakan yang dapat menantang siswa untuk berpikir. 3) menggunakan berbagai variasi yang dapat menghilangkan kebosanan. 4) keluwesan guru dalam pelaksanaan tugas. 5) penekanan pada hal-hal yang bersifat positif. 6) penanaman disiplin diri sendiri.

\section{Hakikat Supervisi Individual}

Secara etimologis supervisi berasal dari kata super artinya atas dan visi yang artinya penglihatan, jadi supervisi adalah posisi yang melihat atau kedudukan yang lebih tinggi daripada yang dilihat. Sedangkan dalam bahasa inggris yaitu 
supervision yang artinya pengawasan (Engkoswara dan Komariah, 2010: 228). Berdasarkan dua hal tersebut, maka supervisi dapat diartikan sebagai pengawasan yang dilakukan oleh orang yang memiliki kedudukan yang lebih tinggi atau orang ahli/professional.

Supervisi pendidikan merupakan usaha membantu guru-guru memperkecil kesenjangan antara tingkah laku mengajar yang nyata dengan tingkah laku mengajar yang ideal. Danim dan Khairil, (2011: 154) mengartikan supervisi pendidikan sebagai upaya peningkatan mutu proses dan hasil pembelajaran melalui bimbingan profesional oleh pengawas sekolah. Bimbingan profesional tersebut memberikan kesempatan kepada guru untuk memperbaiki dan meningkatkan proses belajar.

Berdasarkan pendapat diatas dapat disimpulkan bahwa supervisi merupakan serangkaian kegiatan yang dilakukan oleh pejabat sekolah untuk meningkatkan kemampuannya guru untuk berkembang secara profesional sehingga guru dapat maju dalam menjalankan tugasnya yaitu memperbaiki dan meningkatkan proses pembelajaran. pejabat sekolah yang dimaksud adalah kepala sekolah dan pengawas sekolah.

Ngalim Purwanto (2008: 120) menyebutkan bahwa supervisi terdiri dari dua teknik yaitu perseorangan (individual) dan kelompok. Dalam penelitian ini supervisi teknik individual akan digunakan untuk meningkatkan katerapilan guru dalam mengelola kelas. Menurut Bolla (1982: 4-5) supervisi individual didefinisikan sebagai: a) bantuan yang diberikan kepada guru dalam memperbaiki dan meningkatkan keterampilan mengajarnya dan dapat dilaksanakan untuk kepentingan calon guru dalam pendidikan pra jabatan maupun dalam jabatan; b) supervisi individual terdiri atas tahapan pendahuluan (pre conference), observasi mengajar dan pertemuan balikan; c) pendekatan yang dilakukan bersifat profesional dan humanistik; d) selain menguji kemampuan siswa juga menguji kemampuan pembimbing; e) harus dilakukan oleh lembaga yang kompeten. Melalui kegiatan supervisi individual guru mendapatkan bimbingan, arahan dan pembinaan dari Pengawas Sekolah mengenai berbagai kendala yang dialami dalam melaksanakan tugasnya di sekolah.

Selanjutnya Bolla menjelaskan bahwa tujuan supervisi individual secara umum untuk memperbaiki dan meningkatkan keterampilan mengajar guru di kelas. Sedangkan tujuan khusus dari supervisi adalah untuk (1) menyediakan suatu balikan yang objektif dalam kegiatan mengajar yang dilakukan guru dengan berfokus pada kesadaran dan kepercayaan diri dalam mengajar dan keterampilan-keterampilan dasar mengajar yang diperlukan. (2) mendiagnosis dan membantu memecahkan masalah-masalah pembelajaran. (3) membantu guru mengembangkan keterampilan dalam menggunakan strategi-strategi pembelajaran. (4) membantu guru mengembangkan diri secara terus menerus dalam karir dan profesi mereka secara mandiri. 
Ditjen PMPTK (2008: 8) menyatakan bahwa supervisi individual merupakan salah satu kegiatan yang menyebabkan prediksi yang berbeda terutama di kalangan guru serta kepala sekolah yang diamati oleh pengawas satuan pendidikan. Dalam penelitian ini teknik supervisi yang digunakan adalah observasi kelas.

Ditjen PMPTK (2008: 23) mengatakan bahwa observasi kelas adalah teknik observasi yang dilakukan oleh supervisor terhadap proses pembelajaran yang sedang berlangsung dengan tujuan untuk memperoleh data seobyektif mungkin mengenai aspek-aspek dalam situasi belajar mengajar, kesulitan-kesulitan yang dihadapi oleh guru dalam usaha memperbaiki proses belajar mengajar.

Sedangkan Retno Djohar Juliani (2012: 10) menjelaskan bahwa teknik observasi kelas dilakukan pada saat guru mengajar. Supervisor mengobservasi kelas dengan tujuan untuk memperoleh data tentang segala sesuatu yang terjadi ketika proses belajar mengajar sedang berlangsung. Data ini sebagai dasar bagi supervisor untuk melakukan pembinaan terhadap guru yang sedang diobservasi.

Pendapat Ditjen PMPTK (2008: 23) dan Retno Djohar Juliani (2012: 10) diatas dapat disimpulkan bahwa supervisi individual teknik observasi kelas merupakan kegiatan observasi kelas yang dilakukan oleh supervisor untuk pembinaan terhadap guru dalam rangka upaya memperbaiki proses belajar mengajar.

Lebih lanjut Ditjen PMPTK memaparkan Pelaksanaan observasi kelas ini melalui beberapa tahap, yaitu: (1) perancanaan; supervisor merencanakan dalam menyusun program dalam satu semester atau tahunan. (2) mekanisme observasi; a) persiapan dengan cara memberitahukan kepada guru bahwa akan melakukan observasi kemudian membuat kesepakatan antara supervisor dengan guru mengenai tolak ukur tentang apa yang dioservasi. b) sikap observasi didalam kelas meliputi: memberikan salam kepada guru yang mengajar, mencari tempat duduk yang tidak mencolok, tidak boleh menegur kesalahan guru di dalam kelas, mencatat setiap kegiatan, mempersiapkan isian berupa check list. c) membicarakan hasil observasi antara lain; kepala sekolah mempersiapkan (bisa bertanya pada nara sumber atau perpustakaan), waktu percakapan, tempat percakapan, sikap ramah simpatik tidak memborong percakapan, percakapan hendaknya tidak keluar dari data observasi, guru diberi kesempatan dialog dan mengeluarkan pendapat, kelamahan guru hendaknya menjadi motivasi guru dalam memperbaiki kelemahan, saran untuk perbaikan diberikan yang mudah dan praktis dan kesepakatan perbaikan disepakati bersama dengan menyenangkan. d) membuat laporan percakapan yaitu hasil pembicaraan didokumenkan menurut masing-masing guru yang telah diobservasi dan isi dokumen dimulai dari tanggal, tujuan data yang diperoleh, catatan diskusi, pemecahan masalah dan saran-saran. Mencermati teknik individual di atas, teknik observasi kelas digunakan untuk melakukan supervisi kepada guru untuk meningkatkan keterampilan mengelola kelas. 
Peningkatan Keterampilan Guru SD Dabin III UPTD Dikdas dan LS Wonosegoro - Boyolali dalam Mengelola Kelas Melalui Teknik Supervisi Individual (Beni Supadmono)

\section{Peningkatan Keterampilan Guru Dalam Mengelola Kelas Melalui Supervisi ndividual}

Peningkatkan kualitas guru perlu dilakukan secara terprogram, terstruktur dan berkelanjutan melalui pembinaan profesional oleh kepala sekolah ataupun Pengawas Sekolah sehingga mampu menampung berbagai masalah yang dihadapi oleh guru dalam proses pembelajaran untuk dapat menemukan cara-cara pemecahan permasalahan melalui supervisi akademik. Esensi supervisi individual adalah untuk membantu guru dalam mengembangkan kemampuan profesionalismenya.

Bertolak dari supervisi individual, kebijakan untuk meningkatkan mutu pendidikan pada hakikatnya merupakan keputusan yang strategis. Mutu pendidikan pada umumnya dapat dilihat dari dua segi yaitu segi proses dan segi produk. Dari segi proses, pendidikan dapat disebut bermutu apabila proses pembelajaran berlangsung secara efektif sehingga menghasilkan produk yang berkualitas. Sedangkan dari segi produk, hasil pendidikan disebut bermutu jika peserta didik menunjukkan tingkat penguasaan yang tinggi terhadap tugas-tugas belajar yang dinyatakan dalam prestasi belajar; hasil pendidikan sesuai dengan kebutuhan peserta didik dalam kehidupannya; hasil pendidikan yang sesuai atau relevan dengan tuntutan lingkungan, khususnya dunia kerja (Depdikbud, 1996).

\section{METODE PENELITIAN}

Penelitian ini merupakan penelitian tindakan sekolah (PTS) yang dilakukan di wilayah Dabin III UPTD Dikdas dan LS Kecamatan Wonosegoro Boyolali. Pelaksanaan penelitian tindakan sekolah ini dilakukan melalui tahapan penyusunan proposal penelitian, penyusunan instrument, pelaksanaan tindakan dalam rangka pengumpulan data, analisis data dan pembahasan hasil penelitian serta penyusunan laporan PTS.

Subyek yang dilibatkan dalam penelitian tindakan sekolah ini adalah guru kelas $\mathrm{V}$ berjumlah enam orang. Sumber data primer berasal dari hasil pengukuran variabel penelitian tindakan sekolah berikut: skor keterampilan guru dalam mengembangkan silketerampilan guru dalam mengelola kelas.

Teknik pengumpulan data menggunakan teknik obeservasi kelas. Instrumen observasi yang digunakan adalah instrument keterampilan guru dalam mengelola kelas. Adapun kisi-kisi instrument keterampilan guru dalam mengelola kelas mencakup 18 item dari 9 komponen yaitu; menunjukkan sikap tanggap (item no 1, 2, 3 dan 4), memberi perhatian (item no 5 dan 6), memusatkan perhatian kelompok (item no 7 dan 8), memberikan petunjuk-petunjuk yang jelas ( item no 9), menegur (item no 10, 11, dan 12), memberi penguatan (item no 13 dan 14), memodifikasi tingkah laku (iem no 15), Pendekatan pemecahan masalah (item no 16 dan 17), 
Menemukan dan memecahkan tingkah laku yang menimbulkan masalah (item no18).

Dalam instrumen penilaian terdapat 4 kualifikasi penilaian yaitu 1, 2, 3 dan 4 . Setiap skor yang diperoleh kemudian dibagi dengan skor maksimal dan dikalikan dengan 100 atau $\mathrm{N}=\frac{\text { skor yang diperoleh }}{\text { skor maksimal }} \mathrm{X}$ 100. Adapun kriteria penilaian yaitu: Baik Sekali berada di skor 80 sampai 100, Baik berada pada skor 66 sampai 79, Cukup berada pada skor 56 sampai 65, Kurang berada pada skor 40 sampai 55 sedangkan Kurang Sekali berada pada skor kurang dari 39.

Analisis data yang digunakan adalah teknik analisis deskriptif komparatif. Data kuantitatif yang diperoleh di deskripsikan dalam bentuk kata-kata atau penjelasan. Selanjutkan dilakukan komparasi data untuk memastikan ada tidaknya peningkatan keterampilan guru dalam mengelola kelas. Sebagai tolok ukur keberhasilan pelaksanaan penelitian tindakan sekolah ini ditetapkan indikator kinerja sebesar 10\%. Setelah melakukan analisa terhadap data yang diperoleh, maka dapat disimpulkan bahwa penggunaan supervisi individual menunjukkan peningkatan keterampilan mengelola kelas. Tabel 1 merangkum komparasi kemampuan merencanakan pembelajaran, dari kondisi awal, siklus 1 sampai siklus dan tindakan.

Tabel 1 Komparasi Keterampilan Guru dalam Mengelola Kelas

\begin{tabular}{|l|c|c|}
\hline \multirow{2}{*}{ Pembelajaran } & \multicolumn{2}{|c|}{ Tingkat Sikap Ilmiah } \\
\cline { 2 - 3 } & Mean & \% Kenaikan \\
\hline KondisiAwal & 59,8 & - \\
\hline Siklus 1 & 70 & 10,2 \\
\hline Siklus 2 & 80.5 & 10.5 \\
\hline
\end{tabular}

Dari data dalam Tabel diatas, diperoleh temuan keterampilan guru dalam mengelola kelas a) a) pada kondisi awal, baru mencapai skor 59.8 (skor maksimal 72) b) siklus I, mencapai skor 70 c) pada siklus II, skor guru mencapai 80,5. capaian ini menunjukkan peningkatan keterampilan guru dalam mengelola kelas.

Pada kondisi awal, rata-rata tingkat keterampilan guru dalam mengelola kelas baru mencapai 64,33 (skor maksimal ideal 72); b) pada siklus 1, rata-rata keterampilan guru dalam mengelola kelas mencapai 70. Capaian ini menunjukkan peningkatan keterampilan sebesar $10,2 \%$; c) pada siklus 2, rata-rata keterampilan guru dalam mengelola kelas mencapai 80,5. Data ini menunjukkan peningkatan keterampilan guru dalam mengelola kelas sebesar $10,5 \%$. 
Peningkatan Keterampilan Guru SD Dabin III UPTD Dikdas dan LS Wonosegoro - Boyolali dalam Mengelola Kelas Melalui Teknik Supervisi Individual (Beni Supadmono)

\section{Keberhasilan supervisi individual dalam meningkatkan keterampilan guru dalam mengelola kelas}

Data pada tabel kompetensi guru kondisi dan tindakan menunjukkan temuan skor kemampuan guru melaksanakan pembelajaran pada kondisi awal 59,8, siklus I sebesar 70 dan siklus II sebesar 80,5. Temuan ini mengindikasikan adanya peningkatan tingkat kemampuan guru melaksanakan pembelajaran. Besaran peningkatan $10,5 \%$. Jika dibandingkan dengan indikator kinerja $10 \%$ ternyata temuan tersebut telah mencapai keberhasilan.

\section{SIMPULAN DAN SARAN}

\section{Simpulan}

Berdasarkan hasil penelitian dan pembahasan, dapat disimpulkan bahwa supervisi individual dapat: Meningkakan keterampilan guru dalam mengelola kelas di wilayah Dabin III UPTD Dikdas dan LS Kecamatan Wonosegoro, Kabupaten Boyolali sebesar 10,5\%.

\section{Saran}

Saran yang diajukan dalam penelitian ini adalah,1) supervisi individual terhadap semua guru perlu dilakukan secara periodik, karena supervisi individual ternyata membawa peningkatan keterampilan guru dalam melaksanakan pengelolaan kelas dan hasil belajar siswa jika dilaksanakan secara kolaboratif. 2) guru-guru yang sudah berpengalaman dapat dijadikan supervisor bagi guru lain yang dipandang kurang mampu, untuk meningkatkan kualitas pembelajaran di kelas.

\section{DAFTAR PUSTAKA}

Ade Rukmana dan Asep Suryana. 2006. Pengelolaan Kelas. Bandung: UPI Press.

Bolla. J.I. 1982. Supervisi Pendidikan. Jakarta: Depdiknas

Danim Sudarwan dan Khairil. 2011. Profesi Kependidikan. Bandung: Alfabeta.

Dirjen PMPTK-Depdiknas. 2008. Metode dan Teknik Supervisi. Jakarta: Direktorat Tenaga Kependidikan Direktorat Jenderal Peningkatan Mutu Pendidik dan Tenaga Kependidikan Departemen Pendidikan Nasional

Djamarah, Syaiful Bahri. 2000. Guru dan Anak Didik dalam Interaksi Edukatif. Jakarta: Rineka Cipta.

Engkoswara dan Komariah Aan. 2010. Administrasi Pendidikan. Bandung: Alfabeta Iskandar. 2009. Psikologi Pendidikan: Sebuah Orientasi Baru. Jakarta: Gaung Persada. 
Scholaria, Vol. 6, No. 1, Januari 2016: 74 - 83

Ngalim Purwanto. 2008. Administrasi dan Supervisi Pendidikan. Bandung: Remaja

Retno Djohar Juliani. 2012. Model, Pendekatan, dan Teknik Supervisi Pendidikan Di Perguruan Tinggi. Semarang: Universitas Pandanaran

Rosdakarya.

Syaiful Bahri Djamarah dan Aswan Zain. (2010). Strategi Belajar Mengajar. Jakarta: Rineka Cipta.

Syamsuddin A.R. dan Vismaia S. Damaianti, 2007. Metode Penelitian Pendidikan Bahasa. Bandung: Remaja Rosdakarya Offset

Usman, Moh. Uzer. 2005. Menjadi Guru Profesional. Bandung: PT. Remaja

Wardani, IGAK. 2005. Dasar-Dasar Komunikasi dan Keterampilan Dasar

Mengajar. Jakarta : Universitas Terbuka (PAU-PPAI-UT) 